\title{
Occurrence, distribution and abundance of Halobates micans Eschscholtz, 1822 (Heteroptera, Gerridae) along the southeastern Brazilian coast
}

\author{
Dias, JF* and Lopes, CL. \\ Instituto Oceanográfico, Universidade de São Paulo - USP \\ Praça do Oceanográfico, 191, CEP 05508-120, São Paulo, SP, Brazil \\ *e-mail: junedias@usp.br \\ Received October 24, 2007 - Accepted February 7, 2008 - Distributed February 28, 2009
}

(With 5 figures)

\begin{abstract}
Data collected during an oceanographic cruise along the southeastern Brazilian coast from Cape Frio $\left(22^{\circ} 58^{\prime} \mathrm{S}\right)$ and Paraná (27 50'S) in March 1982 showed that the marine insect Halobates micans occurred along the Southeastern Brazilian Bight, but in lower abundance in low-temperature areas due to the intrusion and upwelling of South Atlantic Central Water, and in low-salinity areas in Coastal Water. Insect capture was higher at night and in the oligotrophic Tropical Water. The number of nymphs and adult females was higher, probably because of an active breeding season during the austral summer. Adult sex ratio was 1.3:1.0 (F:M). Floating gas vesicles of benthic Sargassum spp. and petroleum lumps were used by females for egg-laying.
\end{abstract}

Keywords: Halobates micans, sea-skaters, distribution, southwest Atlantic, Brazilian coast.

\section{Ocorrência, distribuição e abundância de Halobates micans Eschscholtz, 1822 (Heteroptera, Gerridae) na costa sudeste do Brasil}

\section{Resumo}

Dados coletados em um cruzeiro oceanográfico ao longo da costa sudeste do Brasil, entre o cabo Frio (22 $\left.58^{\prime} \mathrm{S}\right)$ e o Paraná ( $\left.27^{\circ} 50^{\prime} \mathrm{S}\right)$, em março de 1982, mostram que o inseto marinho Halobates micans ocorreu no embaiamento sudeste do Brasil, em baixa abundância em locais de baixas temperaturas superficiais, devido à penetração e ressurgência da Água Central do Atlântico Sul, e em locais com salinidade mais baixa devido à presença da Água Costeira. A captura do inseto foi maior durante a noite e na Água Tropical oligotrófica. O número de ninfas e fêmeas adultas foi mais alto, provavelmente por um ativo período reprodutivo no verão austral. As proporções sexuais dos adultos foram 1,3:1,0 (F:M). Vesículas flutuantes de Sargassum spp. e grumos de petróleo (pixe) foram usados pelas fêmeas para oviposição.

Palavras-chave: Halobates micans, distribuição, Atlântico sudoeste, costa do Brasil.

\section{Introduction}

Among the epineustonic community sensu Banse (1975), the most representative organisms are the insects of the genus Halobates (Heteroptera, Gerridae). They are wingless and exclusively marine, spending all stages of their life cycle on the sea-air interface (Zaitsev, 1971). There are only five species of Halobates that are truly pelagic (Cheng, 1982; Cheng et al., 1990; Andersen and Foster, 1992). These open ocean species have some characteristics that allow them to move on the ocean surface film (Cheng and Shulenberger, 1980).

Halobates micans Eschscholtz 1822 is the only oceanic species found in the Atlantic Ocean. The occurrence of Halobates on the Brazilian coast has been reported by several expeditions, e.g. Challenger (1873-1876), Atlantis II (1967-1968), Walther Herwig, and Polarstern (1987) (Cheng, 1973d; Cheng, 1974; Cheng and Schulz-
Baldes, 1981; Schulz-Baldes, 1989), but these expeditions did not cover the Southeast Brazilian Bight.

The goal of the present paper is to contribute with data on the distribution and abundance of this species along the Southeastern Brazilian Bight, and to further the biological information available on this insect species in the South Atlantic.

\section{Material and Methods}

\subsection{Study area}

The sampling area was located between Cape Frio (Rio de Janeiro State) (22 $58^{\circ} \mathrm{S}$ ) and Paraná State $\left(27^{\circ} 50^{\prime} \mathrm{S}\right)$ (Figure 1). Neuston samples were taken during an oceanographic cruise on the R/V Prof. W. Besnard in March 1982, along the southeastern Brazilian coast. 

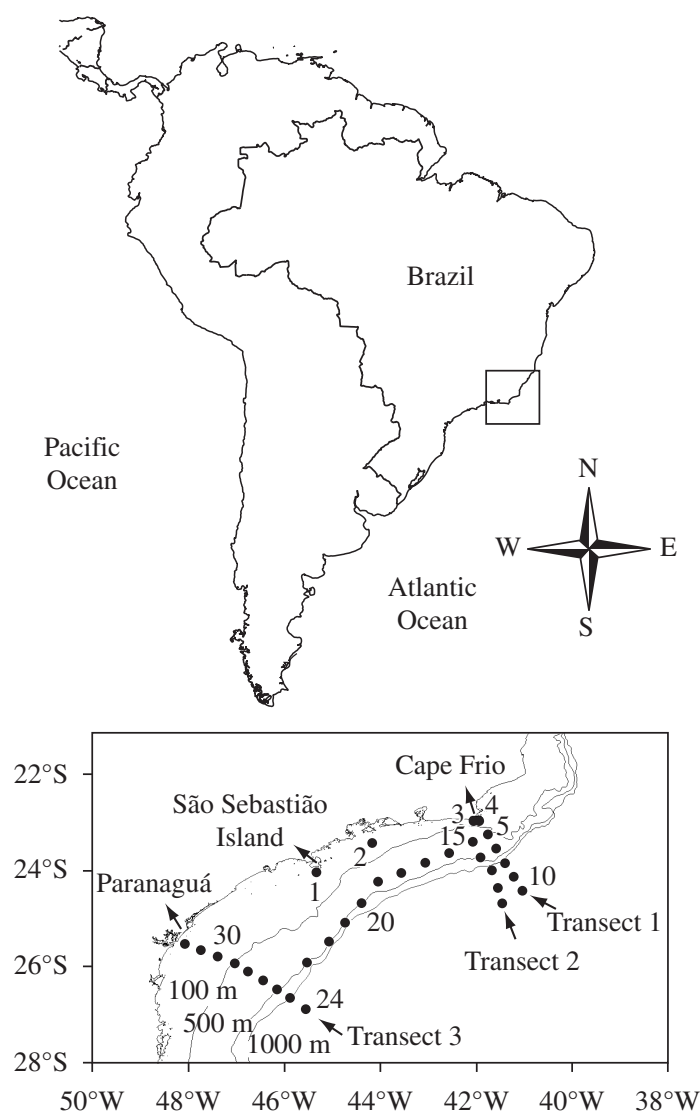

Figure 1. Area of study showing oceanographic stations (dots) during the March 1982 cruise along the southeastern Brazilian coast.

According to Castro and Miranda (1998), there are three main water masses over the Southeast Brazilian Bight during the austral summer and beginning of autumn. Coastal Water (CW) is characterized by low salinity, whereas the offshore Tropical Water (TW) of the Brazil Current flows southward and is characterized by high temperatures and salinities. The South Atlantic Central Water (SACW) is a typical oceanic water mass with temperatures below $20^{\circ} \mathrm{C}$ and salinities above 36.4. When intruding onto the continental shelf, SACW occupies the bottom layer and mixes with the warmer and fresher Coastal Water (CW). Depending on the wind condition, an upwelling of SACW can occur, reaching the surface in the northern part of the study area, in the Cape Frio region. The effects of the Cape Frio upwelling can reach the São Paulo shelf, $400 \mathrm{~km}$ to the southwest (Lorenzzetti and Gaeta, 1996).

\subsection{Neuston sampling and analysis}

Thirty-two samples were collected using a modified David neuston net (David, 1965), with a catamaran frame sustaining a $4 \mathrm{~m}$ long net of $333 \mu \mathrm{m}$ mesh size, and a $30 \times 15 \mathrm{~cm}$ rectangular mouth opening. Samples were caught from the sea surface to a depth of $7.5 \mathrm{~cm}$.
Stations on this cruise were 20 nautical miles apart. At each station, the net was trawled starboard at mid-ship, with a speed of $0.9 \mathrm{~m} / \mathrm{s}$, for 10 minutes. In spite of irregular submergence of the net or its skipping out of the water during the trawls under different weather and sea conditions, the area of each trawl was estimated as $185.24 \mathrm{~m}^{2}$.

After capture, samples were preserved on board in a $5 \%$ formalin-seawater solution. Since the cruise took place at the end of the austral summer and beginning of autumn, the photoperiods adopted were: night $=7: 00 \mathrm{PM}$ to $5: 00 \mathrm{AM}$; day $=7: 00 \mathrm{AM}$ to $5: 00 \mathrm{PM}$; dusk-dawn $=$ 5:00 to 7:00 PM and 5:00 to 7:00 AM.

Before each trawl, surface water temperature was measured and water samples for salinity determination were taken. A TS diagram was plotted, based on water mass boundary data established by Castro and Miranda (1998). Other abiotic data were also collected: wind speed (Beauford scale), sea state and weather conditions according to international scales.

In the laboratory, the samples were sorted and the adult Halobates specimens were identified using the key presented by Herring (1961). The insects were also sorted by life classes (instars) (Cheng, 1991), and last instar nymphs and adults were sexed. A chi-square test was used to verify departures from a 1:1 sex ratio. Ratio of night/day catches was used to indicate differences in capture between light and dark periods. Differences between numbers of insects collected north and south of São Sebastião Island were tested ( $t$-test). Abiotic parameters such as depth, temperature, salinity, wind speed and distance from the coast were tested by simple linear correlation to analyse if any of them could explain Halobates distribution variability. Differences in numbers of insects collected in relation to distance from the coast were tested by simple linear correlation for the transects.

\section{Results}

Sea water temperature at stations ranged from 24.8 to $27.0{ }^{\circ} \mathrm{C}$, and salinity ranged from 33.4 to 37.1 . A scattered T-S diagram of the surface water along the Brazilian coast during the March 1982 cruise identified three groups of stations: 1 . those with low temperatures (below $20^{\circ} \mathrm{C}$ ) and high salinity (South Atlantic Central Water); 2. those with high temperatures $\left(>20^{\circ} \mathrm{C}\right)$ and high salinity (>36.4) (Tropical Water); and 3. those with high temperatures and low salinity (Coastal Water) (Figure 2a). The water masses at the surface differed at different stations. Tropical Water predominated in the continental shelf from the $100 \mathrm{~m}$ isobath to offshore areas, and the cold South Atlantic Central Water was detected only in the Cape Frio coastal area stations. Coastal Water predominated in coastal areas, mainly in regions with a large estuarine system, like Paranaguá (Figure 2b).

The wind speed ranged from 0 to 22 knots, sea state ranged from calm (sea state 1 ) to wavy (sea state 3 ), and the weather conditions from clear $(0)$ to partially covered 
(1) to a continuous layer of clouds (2), but without rain or drizzle (Table 1).

All adult insects collected were identified as Halobates micans Eschscholtz, 1822 (Figure 3a). Specimens were found from the Cape Frio region (Rio de Janeiro State) to Paranaguá (Paraná State), and from the coastal area to approximately 100 or 120-180 nautical miles offshore along transects at those two locations.

Halobates micans densities were higher in areas deeper than the $100 \mathrm{~m}$ isobath, mainly in transect 3 , between the 100 and $500 \mathrm{~m}$ isobaths, and along the $500 \mathrm{~m}$ isobath in the southern area of São Sebastião Island. Only one station of transect 1 , in the northern area, presented more than 40 insects (Figure 4).

A total of 545 Halobates micans were collected: $83.2 \%$ of the specimens were nymphs and $16.8 \%$ were adults $(9.7 \%$ females and $7.1 \%$ males) (Table 2). Sex ratio, considering only the adults, did not differ significantly: 51 females to 38 males, or 1.3: $1.0(p=0.2034)$. However, if nymphs of the last instar were taken into account, the sex ratio was the opposite: 67 females to 91 males, or 1.0: 1.3 favouring males ( $p=0.2034)$. The first two nymphal stages were the most abundant (Figure 5).
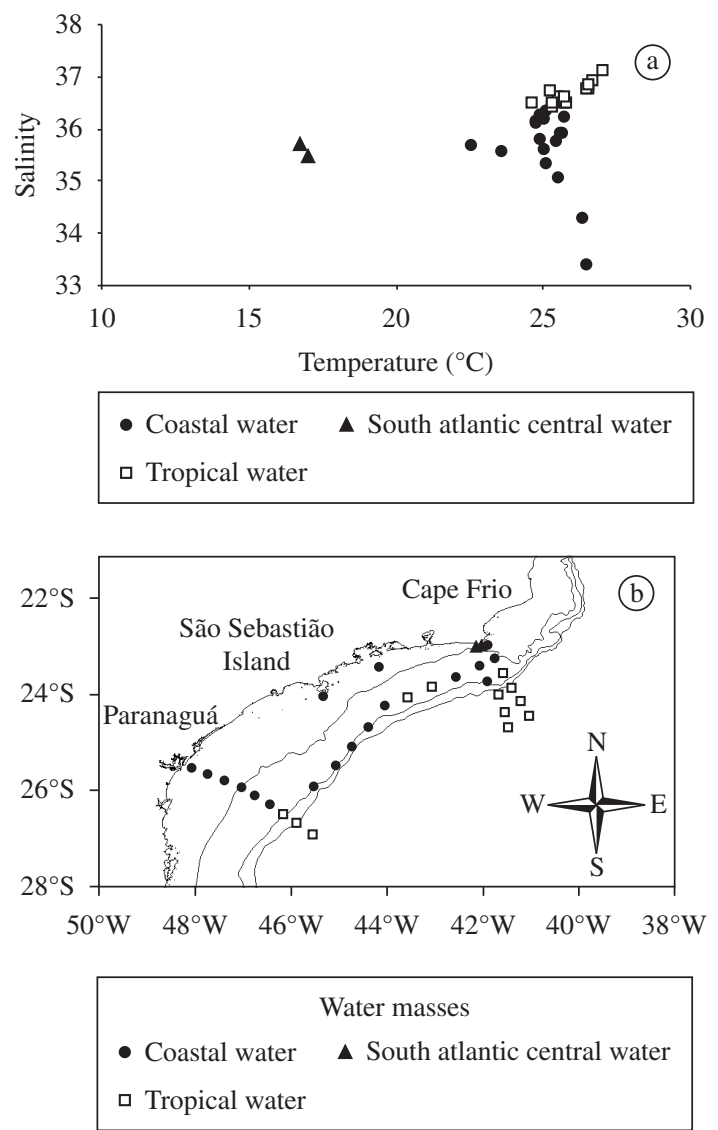

Figure 2. a) TS scatter plot and b) water masses during the March 1982 cruise along the southeastern Brazilian coast.
The number of individuals caught was higher during the night, with maximum abundance at the station featuring $24.9^{\circ} \mathrm{C}$ temperature and 35.8 salinity. Relative frequency at night was $60.2 \%$. In the light periods it was $27.7 \%$, and in the dusk-dawn periods $12.1 \%$. The stations where only nymphs of different stages were collected occurred only during the day (Table 2).

Comparison of the number of insects per station in each photoperiod indicates that 27.3 insects were collected at night, 10.8 during the day and 11.0 in the dusk-dawn periods (Table 3 ). The nymph/adult ratio was

Table 1. General data on the neuston tows performed off the Brazilian coast in March 1982 during R/V Prof. W. Besnard cruise.

\begin{tabular}{|c|c|c|c|}
\hline $\begin{array}{l}\text { Survey } \\
\text { station }\end{array}$ & $\begin{array}{c}\text { Speed } \\
\text { (knots) }\end{array}$ & $\begin{array}{c}\text { Sea } \\
\text { state }^{(1)}\end{array}$ & $\begin{array}{c}\text { Weather } \\
\text { condition }^{(2)}\end{array}$ \\
\hline 1 & 22 & 3 & 2 \\
\hline 2 & 14 & 2 & 2 \\
\hline 3 & 2 & 1 & 0 \\
\hline 4 & 0 & 0 & 1 \\
\hline 5 & 4 & 1 & 1 \\
\hline 6 & 5 & 1 & 1 \\
\hline 7 & 7 & 1 & 0 \\
\hline 8 & 14 & 2 & 1 \\
\hline 9 & 8 & 2 & 1 \\
\hline 10 & 10 & 2 & 1 \\
\hline 11 & 10 & 2 & 1 \\
\hline 12 & 12 & 1 & 1 \\
\hline 13 & 8 & 2 & 1 \\
\hline 14 & 10 & 3 & 1 \\
\hline 15 & 7 & 1 & 1 \\
\hline 16 & 3 & 1 & 1 \\
\hline 17 & 0 & 1 & 1 \\
\hline 18 & 3 & 1 & 1 \\
\hline 19 & 0 & 1 & 1 \\
\hline 20 & 13 & 1 & 1 \\
\hline 21 & 12 & 2 & 1 \\
\hline 22 & 10 & 1 & 1 \\
\hline 23 & 12 & 1 & 1 \\
\hline 24 & 12 & 2 & 1 \\
\hline 25 & 10 & 3 & 1 \\
\hline 26 & 13 & 2 & 1 \\
\hline 27 & 13 & 2 & 2 \\
\hline 28 & 7 & 1 & 1 \\
\hline 29 & 6 & 2 & 1 \\
\hline 30 & 12 & 2 & 1 \\
\hline 31 & 12 & 1 & 1 \\
\hline 32 & 12 & 1 & 1 \\
\hline
\end{tabular}

(1) calm (sea state 1 ) to wavy (sea state 3 ); ${ }^{(2)} 0=$ clear, $1=$ partially covered, 2 = continuous layer of clouds. 


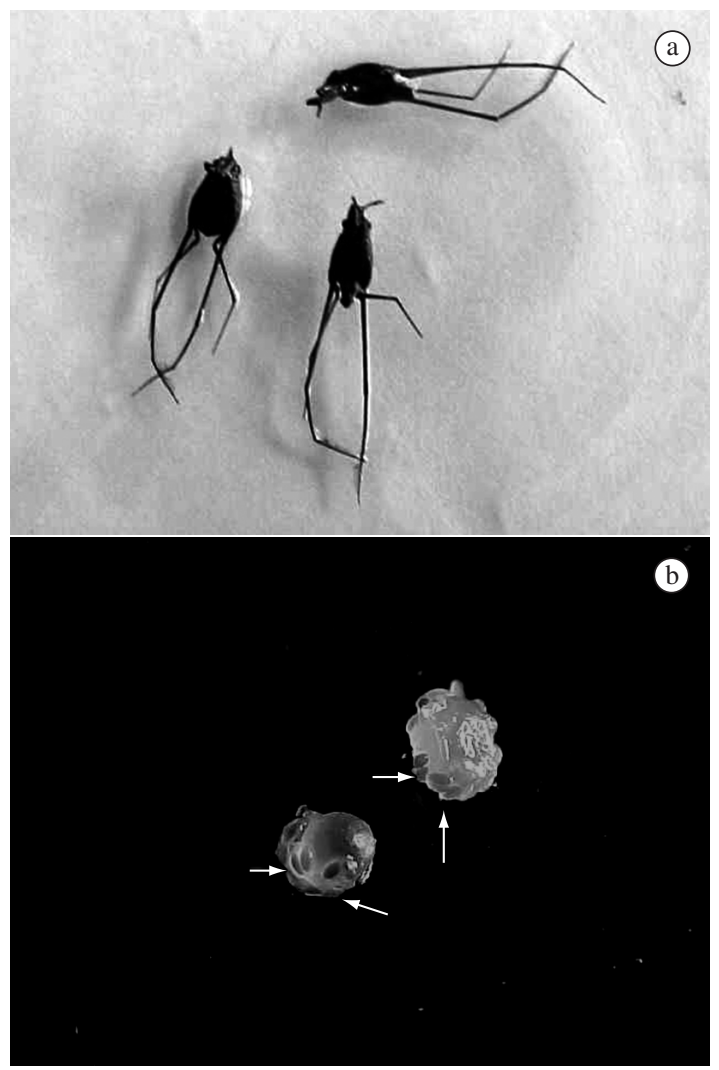

Figure 3. a) Adult Halobates micans male and females; floating gas vesicles of b) Sargassum with Halobates eggs. a) Insects size $=10 \mathrm{~mm}$ and b) Sargassum vesicle $(3 \mathrm{~mm})$.

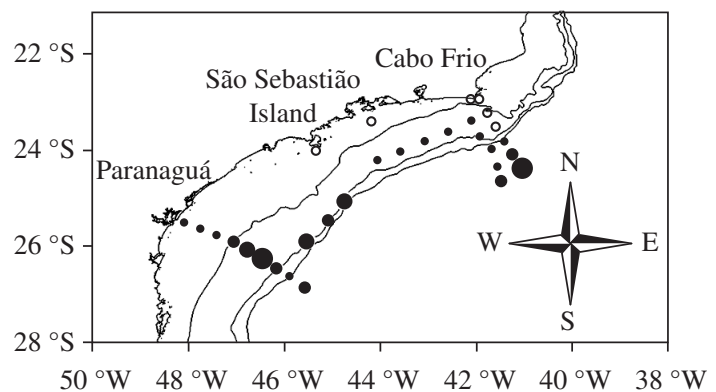

$$
\begin{array}{|ll|}
\hline \multicolumn{2}{|c|}{\text { Individuals } / 185.25 \mathrm{~m}^{2}} \\
\text { - } 0 & -41 \text { to } 60 \\
\text { - } 1 \text { to } 20 & 61 \text { to } 80 \\
\text { - } 21 \text { to } 40 & \\
\hline
\end{array}
$$

Figure 4. Occurrence and abundance of Halobates micans in the March 1982 cruise along southeastern Brazil.

higher during the day (24.2), dropping to 4.5 in the duskdawn period, and to 3.6 during the night (Table 3).

There was a tendency for more individuals to be collected in the northern region, from São Sebastião Island to Cape Frio $(p=0.001)$. From the abiotic parameters

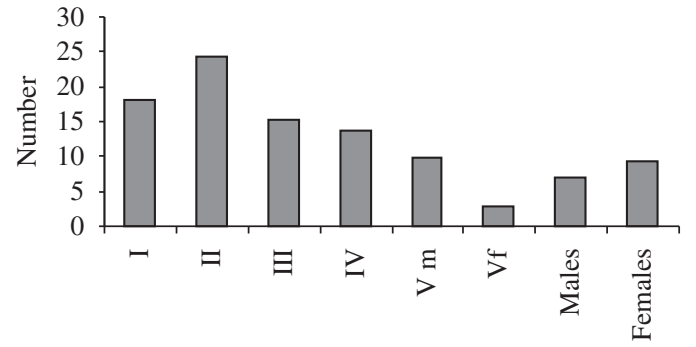

Figure 5. Developmental stages (instar) frequency distribution of Halobates micans during March 1982 along southeastern Brazil. Ad = adults.

tested, only in transect 1 (stations 5 to 10) did a relationship between the distance from the coast and number of insects emerge $(\mathrm{p}=0.0252)$.

Batches of $H$. micans eggs were found on floating gas vesicles of benthic Sargassum spp. at 2 stations (Figure 3b), and on petroleum lumps at four stations. The mean number of eggs. $\mathrm{mm}^{-2}$ on petroleum lumps varied from 1.44 to $1.63 . \mathrm{mm}^{-2}$, and from 7 to 55 per Sargassum vesicle. Ecdises or cast skins from all stages of development were also found.

\section{Discussion}

The number of Halobates micans specimens captured during the night was twice as high as those found during the day. Many more adults were captured at night compared to nymphs. The number of individuals caught during the day was probably underestimated, since Halobates micans can move at speeds between 0.5 and $1.0 \mathrm{~m} / \mathrm{s}$ (Cheng, 1974) while the speed of the neuston net trawl was $0.9 \mathrm{~m} / \mathrm{s}$. There is also the possibility of net avoidance, since adults can see the approaching net and are able to escape by skating away (Cheng, 1973a, 1973c; Cheng and Enright, 1973). These insects can also jump (Cheng, 1973b), and may be able to avoid the net that way also. During the night, two factors may contribute to the increase in number of insects captured: the absence of sufficient light to enable the insects to see the net, and their attraction to night lights on the ship.

The ratio between the sexes found herein was similar to that reported by Cheng (1971) for Melanesia, with a predominance of adult females in the samples. Generally, this predominance is an advantage for oviparous gonochoristic species, inasmuch as each male can mate with several females. However, if the fifth instar is considered, these results were reversed, that is, there was a predominance of males.

Halobates micans is non-randomly distributed across the ocean surface (Cheng and Shulenberger, 1980; Cheng and Holdway, 1995). The abiotic variables which may influence the occurrence and distribution of Halobates are temperature, salinity, surface currents, winds and other meteorological factors, as well as the presence of float- 
Table 2. Occurrence of adults and nymphs by period of the day and nymph/adult ratio of Halobates micans in the March 1982 R/V Prof. W. Besnard cruise. N = number of individuals.

\begin{tabular}{|c|c|c|c|c|c|c|c|c|c|c|}
\hline \multirow{3}{*}{$\begin{array}{l}\text { Survey } \\
\text { station }\end{array}$} & \multirow{3}{*}{$\begin{array}{c}\text { Time } \\
\text { (h:min.) }\end{array}$} & \multirow{3}{*}{$\begin{array}{c}\text { Total } \\
\text { number }\end{array}$} & \multicolumn{8}{|c|}{ Developmental stages } \\
\hline & & & \multicolumn{6}{|c|}{ Nymphal stages (\%) } & \multicolumn{2}{|c|}{ Adults (\%) } \\
\hline & & & $\mathbf{I}$ & II & III & IV & $\mathbf{V} \mathbf{m}$ & Vf & males & females \\
\hline 1 & 8:05 PM & 0 & - & - & - & - & - & - & - & - \\
\hline 2 & $7: 32 \mathrm{AM}$ & 0 & - & - & - & - & - & - & - & - \\
\hline 3 & 6:00 PM & 0 & - & - & - & - & - & - & - & - \\
\hline 4 & $6: 33 \mathrm{AM}$ & 0 & - & - & - & - & - & - & - & - \\
\hline 5 & 8:27 AM & 0 & - & - & - & - & - & - & - & - \\
\hline 6 & 11:47 AM & 0 & - & - & - & - & - & - & - & - \\
\hline 7 & 3:13 PM & 0 & - & - & - & - & - & - & - & - \\
\hline 8 & 7:00 PM & 3 & - & 67.0 & - & - & - & - & 33.0 & - \\
\hline 9 & 10:00 PM & 33 & - & 36.4 & 27.3 & 33.3 & - & - & - & 3.0 \\
\hline 10 & 2:36 AM & 42 & 2.4 & 21.4 & 24.2 & 14.3 & 16.7 & 24.2 & 2.4 & 4.7 \\
\hline 11 & $6: 10 \mathrm{AM}$ & 27 & 7.4 & 29.6 & 22.2 & 29.6 & 7.4 & - & - & 3.7 \\
\hline 12 & $9: 55 \mathrm{AM}$ & 9 & 22.2 & 33.3 & 33.3 & 11.1 & - & - & - & - \\
\hline 13 & 2:20 PM & 4 & - & - & - & - & - & 25.0 & - & 75.0 \\
\hline 14 & 6:05 PM & 3 & - & 33.3 & 33.3 & - & - & - & - & 33.3 \\
\hline 15 & 9:20 PM & 8 & - & - & - & 25.0 & - & - & 37.5 & 37.5 \\
\hline 16 & 1:50 AM & 14 & 7.1 & 14.3 & 14.3 & 7.1 & 35.7 & - & 7.1 & 14.3 \\
\hline 17 & 6:00 AM & 16 & 43.7 & 6.3 & 6.3 & 18.7 & 18.7 & - & - & 6.3 \\
\hline 18 & $9: 45$ AM & 9 & 55.6 & - & 22.2 & 22.2 & - & - & - & - \\
\hline 19 & 2:15 PM & 2 & - & - & 50.0 & 50.0 & - & - & - & - \\
\hline 20 & 6:55 PM & 20 & 30.0 & - & 5.0 & 15.0 & 5.0 & - & 15.0 & 30.0 \\
\hline 21 & 11:03 PM & 43 & 30.2 & 20.9 & 7.0 & 18.6 & 7.0 & 2.3 & 9.3 & 4.6 \\
\hline 22 & 3:34 AM & 25 & 20.0 & - & 20.0 & 25.0 & 4.0 & - & 20.0 & 20.0 \\
\hline 23 & $7: 40 \mathrm{AM}$ & 49 & 49.0 & 16.3 & 22.5 & 12.2 & - & - & - & - \\
\hline 24 & 3:13 PM & 26 & 15.4 & 42.3 & 15.4 & 7.7 & 3.8 & 3.8 & 3.8 & 7.7 \\
\hline 25 & 7:17 PM & 14 & 28.6 & 35.7 & 14.3 & 7.1 & 7.1 & - & 7.1 & - \\
\hline 26 & 11:05 PM & 21 & 19.0 & 19.0 & 14.3 & 14.3 & - & - & 23.8 & 9.5 \\
\hline 27 & $1: 52 \mathrm{AM}$ & 76 & 3.9 & 3.9 & 3.9 & 6.6 & 35.5 & 6.6 & 14.5 & 25.0 \\
\hline 28 & 4:50 AM & 49 & 14.3 & 51.0 & 18.4 & 6.1 & 4.1 & - & 4.1 & 2.0 \\
\hline 29 & 7:44 AM & 24 & 37.5 & 25.0 & 20.8 & 16.7 & - & - & - & - \\
\hline 30 & $10: 45 \mathrm{AM}$ & 6 & - & 83.3 & 16.7 & - & - & - & - & - \\
\hline 31 & 1:40 PM & 19 & - & 84.2 & 15.8 & - & - & - & - & - \\
\hline 32 & 4:40 PM & 3 & 33.3 & 66.7 & - & - & - & - & - & - \\
\hline Total & & 545 & 18.0 & 24.2 & 15.2 & 13.6 & 9.7 & 2.9 & 7.0 & 9.3 \\
\hline
\end{tabular}

Table 3. Population structure of Halobates micans collected along the Brazilian coast on March 1982.

\begin{tabular}{lrrc}
\hline & Night & Day & Dusk-dawn \\
\hline Adults & 71 & 6 & 12 \\
Nymphs & 257 & 145 & 54 \\
Total & 328 & 151 & 66 \\
\hline Stations per period & 12 & 14 & 6 \\
Total/stations/period & 27.3 & 10.8 & 11.0 \\
\hline Nymphs/adults & 3.6 & 24.2 & 4.5 \\
\hline
\end{tabular}

ing material (Savilov, 1967; Scheltema, 1968; Cheng, 1973b; 1974; Cheng and Shulenberger, 1980; Stoner and Humphris, 1985 Ikawa et al., 2004). Cheng (1992) confirms that in the Atlantic numbers of this species vary as a function of surface water temperature.

The highest insect abundance occurred at the station with $24.9{ }^{\circ} \mathrm{C}$ temperature and 35.8 salinity, where Tropical Water predominated. This water mass is oligotrophic (Aidar et al., 1993) and the occurrence of $H$. micans in this water mass agrees with the suggestion 
that this species reaches higher density under oligotrophic conditions (Cheng et al., 1990). On the other hand, there were no records of $H$. micans in the coastal area of Cape Frio region at stations where temperatures were lower (from 16.8 to $17{ }^{\circ} \mathrm{C}$ ), which may be attributed to the coastal upwelling, when South Atlantic Central Water intrudes over the continental shelf and reaches the surface. This water mass presents high nutrient content and is responsible for the enrichment in primary production of the water column along the Southeast Brazilian Bight, by up to 10-fold (Aidar et al., 1993).

In our study the open-ocean $H$. micans was collected in low-salinity near-shore stations under Coastal Water influence in the area off Paranaguá. Andersen and Foster (1992) reported that this species can occasionally occur in near-shore regions, but lower, suggesting tolerance to salinity variations. Cheng (1985) reported considerable variation in the ability of Halobates species to survive in different salinities.

Likewise, the condition of the sea, which varied from wavy-calm to slightly rolling, with wave height between 0 and $1.25 \mathrm{~m}$, did not seem to affect insect capture. At two collecting stations with sea state 3 , relative frequency and number of individuals per square meter were low, but not the lowest reported in this study. According to Savilov (apud Cheng, 1973b), even under conditions of sea state 6 or 7 it was possible to attract these insects using night-lights. The presence of eggs, ecdises and first three instar nymphs indicated breeding during austral summer, when sea surface temperatures were higher. An active breeding season in the Gulf of Mexico during summer was reported by Cheng and Wormuth (1992).

Little is known about the role Halobates plays in the neustonic community. Senta et al. (1993) found Halobates remains in the stomach contents of six species of fishes, mainly carangids, and discussed the occurrence of halobatids in other species' diets. Sea birds and sea turtles have also been reported as Halobates predators (Senta et al., 1993; Witherington, 2002). Bull et al. (1977), Cheng et al. (1984) and Schulz-Baldes (1989) have suggested that Halobates micans could be used as a bioindicator of cadmium distribution in the surface waters. Since these insects live at the sea-air interface, they could also be used as indicators of changes in ocean surface layer brought about by anthropogenic action.

In this study, Halobates was mainly collected from the oligotrophic Tropical Water along the subtropical Brazilian coast, and no captures were made in the enriched South Atlantic Central Water. More studies are needed to provide a better understanding of the distribution and ecological role of this insect along the Brazilian coast.

Acknowledgements - The first author is grateful to P. L. Ho, M. Katsuragawa, V. F. Hadel, A. P. Santos, M. A. V. Petti, M. M. Mahiques, M.H. Okgawara and D. B. Moraes. Very special thanks to Dr L. Cheng for her interest and enthusiasm and to Dr M. B. B. Kutner and Dr M. S. Almeida Prado Por. We also thank Dr Y. Matsuura†("in memoriam"), who allowed the use of the neustonic material, K. Suzuki, for her help in sorting neustonic samples, and two anonymous referees. Samples where collected during the course of an institutional project supported by FINEP (Financiadora de Estudos e Projetos) and by the Instituto Oceanográfico - Universidade de São Paulo, São Paulo, Brazil. The first author received a scholarship grant from FAPESP (Fundação de Amparo à Pesquisa do Estado de São Paulo), Proc. No 83/2375-4.

\section{References}

AIDAR, E., GAETA, SA., GIANESELLA-GALVÃO, SMF., KUTNER, MBB. and TEIXEIRA, C., 1993. Ecossistema costeiro subtropical: nutrientes dissolvidos, fitoplâncton e clorofila-a e suas relações com as condições oceanográficas na região de Ubatuba, SP. Publicação especial do Instituto oceanográfico, no. 10, p. 9-43.

ANDERSEN, NM. and FOSTER, WA., 1992. Sea skaters of India, Sri Lanka, and the Maldives, with a new species and a revised key to Indian Ocean species of Halobates and Asclepios (Hemiptera, Gerridae). Journal of Natural History, vol. 26, p. 533-553.

BANSE, K., 1975. Pleuston and neuston: on the categories of organisms in the uppermost pelagial. Internationale Revue der gesamten Hydrobiologie, vol. 60, no. 4, p. 439-447.

BULL, KR., MURTON, RK., OSBORN, D., WARD, P. and CHENG, L., 1977. High levels of cadmium in Atlantic seabirds and sea-skaters. Nature, vol. 269, p. 507-509.

CASTRO, BM. and MIRANDA, LB., 1998. Physical oceanography of the western Atlantic continental shelf located between $4^{\circ} \mathrm{N}$ and $34^{\circ} \mathrm{S}-$ coastal segment $(4, \mathrm{~W})$. In ROBINSON, AR. and BRINK, KH. (Eds.). The Sea. Oxford: John Wiley \& Sons. p. 209-251.

CHENG, L., 1971. Ocean striders from Melanesia (Hemiptera: Gerridae, Halobates spp). Cahiers: Office de la Recherche Scientifique et Technique Outre-Mer, série Océanografique, vol. 9, no. 4, p. 513-518.

-, 1973a. Can Halobates dodge nets? By daylight??. Limnology and Oceanography, vol. 18, no. 4, p. 663-665

-, 1973b. Halobates. Oceanography and Marine Biology Annual Review, vol. 11, p. 223-235.

-, 1973c. Marine and freshwater skaters: differences in surface fine structures. Nature, vol. 242, no. 5393, p. 132-133.

-, 1973d. The ocean strider Halobates (Heteroptera: Gerridae) in the Atlantic Ocean. Oceanology, vol. 13, p. 564-570.

-, 1974. Notes on the ecology of the oceanic insect Halobates. Marine Fisheries Review, vol. 36, no. 2, p. 1-7.

-, 1982. Insects. In SCHWARTZ, ML. (Ed.). The encyclopaedia of beaches and coastal environments. Strandsburg: Hutchinson Ron Publ. Company. 940 p.

-, 1985. Biology of Halobates (Heteroptera: Gerridae). Annиal Review of Entomology, vol. 30, p. 111-135.

-, 1991. The endemic sea-skater Halobates alluaudi Bergroth, 1893 (Hemiptera: Gerridae) in the Seychelles. The Raffles Bulletin of Zoology, vol. 39, no. 1, p. 161-168. 
CHENG, L. and ENRIGHT, JT., 1973. Can Halobates dodge nets?: By moonlight?. Limnology and Oceanography, vol. 18, no. 4, p. 666-669.

CHENG, L. and HOLDWAY, P., 1995. Populations of Halobates (Hemiptera: Gerridae) across two oceans. The Raffles Bulletin of Zoology, vol. 43, no. 2, p. 313-327.

CHENG, L. and SCHULZ-BALDES, M., 1981. Frequency and population composition of Halobates micans (Heteroptera: Gerridae) from the central and south Atlantic Ocean. Meteor Forschung-Ergebnisse, vol. 33, p. 17-21.

CHENG, L. and SHULENBERGER, E., 1980. Distribution and abundance of Halobates species (Insecta: Heteroptera) in the Eastern tropical Pacific. Fishery Bulletin, vol. 78, no. 3, p. $579-591$.

CHENG, L. and WORMUTH, JH., 1992. Are there separated populations of Halobates in the Gulf of Mexico?. Bulletin of Marine Science, vol. 50, no. 2, p. 307-319.

CHENG, L., BAARS, MA. and OOSTERHUIS, SS., 1990. Halobates in the Banda Sea (Indonesia): monsoonal differences in abundance and species composition. Bulletin of Marine Science, vol. 47, no. 2, p. 421-430.

CHENG, L., SCHULZ-BALDES, M. and HARRISON, CS., 1984. Cadmium in ocean-skaters, Halobates sericeus (Insecta), and their seabird predators. Marine Biology, vol. 79, no. 3, p. 321-324.

DAVID, PM., 1965. The neuston net. A device for sampling the surface fauna of the ocean. Journal of Marine Biology Association of the Unted Kingdon, vol. 45, p. 313-320.

HERRING, JL., 1961. The genus Halobates (Hemiptera: Gerridae). Pacific Insects, vol. 3, no. 2-3, p. 223-305.
IKAWA, T., OKABE, H., HOSHIZAKI, S., KAMIKADO, T. and CHENG, L., 2004. Distribution of the oceanic insects Halobates (Hemiptera: Gerridae) off the south coast of Japan. Entomological Science, vol. 7, p. 351-357.

LORENZZETTI, JA. and GAETA, SA., 1996. The Cape Frio Upwelling effect over the South Brazil Bight northern sector shelf waters: a study using AVHRR images. In $18^{\circ}$ Congress International Society of Photogrametry and Remote Sensing ISPRS. Vienna: [s.n]. p. 448-453.

SAVILOV, AI., 1967. Oceanic insects Halobates (Hemiptera: Gerridae) in the Pacific ocean. Oceanology, vol. 8, no. 2, p. $325-336$.

SCHELTEMA, RS., 1968. Ocean insects. Oceanus, vol. 14, no. 3, p. 9-12.

SCHULZ-BALDES, M., 1989. The sea-skater Halobates micans: an open ocean bioindicator for cadmium distribution in Atlantic surface waters. Marine Biology, vol. 102, no. 2, p. 211-215.

SENTA, T., KIMURA, M. and KANBARA, T., 1993. Predation of fishes on open-ocean species of sea-skaters (Halobates spp.). Japanese Journal of Ichthyology, vol. 40, no. 2, p. 193-198.

STONER, AW. and HUMPHRIS, SE., 1985. Abundance and distribution of Halobates micans (Insecta: Gerridae) in the northwest Atlantic. Deep-Sea Research Part I, vol. 32, no. 6, p. $733-739$.

ZAITSEV, YP., 1971. Marine neustonology. Traduzido por A. MERCADO. Jerusalém: Israel Program for Scientific Translations. 207 p.

WITHERINGTON, BE., 2002. Ecology of neonate loggerhead turtles inhabiting lines of downwelling near a Gulf Stream front. Marine Biology, vol. 140, no. 4, p. 843-853. 